\title{
Pengaruh Inovasi Produk, Promosi, Electronic Word of Mouth (eWOM), dan Citra Merek terhadap Minat Beli Produk Pucelle pada Masa Pandemi Covid-19 di Surabaya
}

\author{
*Anita Sanana, Muslichah Erma W, Enny Istanti \\ Program Studi Manajemen Fakultas Ekonomi dan Bisnis \\ Universitas Bhayangkara Surabaya, Indonesia
}

DOI: 10.46821/benchmark.v2i1.218

\begin{abstract}
Abstrak
Globalisasi merupakan proses kemajuan teknologi yang dimana harus dihadapi oleh para pebisnis. Dalam era globalisasi saat ini, sebuah perusahaan dituntut untuk selalu meningkatkan kualitas dan kuantitas pemasaran melalui hasil produksi maupun jasanya untuk dapat bersaing dengan yang lain. Tujuan dari penelitian ini adalah untuk mengetahui pengaruh Inovasi Produk, Promosi, Electronic Word Of Mouth (EWOM) dan Citra Merek terhadap Minat Beli produk Pucelle pada masa pandemi Covid-19 di Surabaya. Penelitian ini menggunakan pendeketan kuantitatif dengan pengumpulan data menggunakan penyebaran kuesioner. Populasi dari penelitian ini adalah seluruh pelanggan Pucelle dengan 96 orang dijadikan sampel dengan metode probability sampling. Metode analisis yang digunakan ialah dengan analisis regresi linear berganda dengan uji hipotesis yaitu uji $\mathrm{F}$ dan uji t. Hasil dari penelitian ini menunjukan bahwa Inovasi Produk, Promosi, Electronic Word Of Mouth (eWOM) dan Citra Merek berpengaruh signifikan secara simultan dan parsial terhadap Minat Beli. Variabel Electronic Word Of Mouth berpengaruh dominan terhadap Minat Beli produk Pucelle pada masa pandemi Covid-19 di Surabaya.

Kata Kunci: Inovasi Produk, Promosi, Electronic Word of Mouth (EWOM) dan Citra Merek dan Minat Beli.

Abstract

Globalization is a technological advancement which must protect business people. In the current era of globalization, a company is required to always improve the quality and quantity of marketing through its production and services to be able to compete with others. The purpose of this study was to see the effect of Product Innovation, Promotion, Electronic Word Of Mouth (EWOM) and Brand Image on Purchase Intention for Pucelle products during the Covid-19 pandemic in Surabaya. This study uses a quantitative approach with data using questionnaires. The population of this study were all Pucelle customers with 96 people sampled using probability sampling methods. The method of analysis used is multiple linear regression analysis with hypothesis testing, namely the $\mathrm{F}$ test and $\mathrm{t}$ test. The results of this study indicate that Product Innovation, Promotion, Electronic Word Of Mouth (eWOM) and Brand Image have a significant effect simultaneously and partially on Purchase Interest. The Electronic Word Of Mouth variable has a dominant effect on purchase interest in Pucelle products during the Covid-19 pandemic in Surabaya.
\end{abstract}

Keywords: Product Innovation, Promotion, Electronic Word of Mouth (eWOM) and Brand Image and Purchase Interest.

*Corresponding Author:

Hal: 11-24

Email: anitasanana@gmail.com 


\section{PENDAHULUAN}

Globalisasi merupakan proses kemajuan teknologi yang dimana harus dihadapi oleh para pebisnis. Dalam era globalisasi saat ini, sebuah perusahaan dituntut untuk selalu meningkatkan kualitas dan kuantitas pemasaran melalui hasil produksi maupun jasanya untuk dapat bersaing dengan yang lain. Globalisasi yang terjadi di bidang ekonomi ini sangat berpengaruh terhadap perdagangan antara beberapa negara yang bersifat bebas. Pemarasan menjadi faktor penting dalam menunjang perdagangan bebas pada masa kini. Sudaryono (2016:41), pemasaran adalah proses bisnis yang berusaha menyelaraskan antara sumber daya manusia, financial dan fisik organisasi dengan kebutuhan dan keinginan para pelanggan dalam konteks strategi kompetitif. Berbagai macam caradan kegiatan dilakukan setiap individu didalam suatu masyarakat, tidak hanya untuk sekedar bertahan hidup tapi juga untuk menikmati hidup dengan semaksimal mungkin (Istanti, 2019, 16.

Persaingan di bursa tenaga kerja akan semakin meningkat menjelang pemberlakuan pasar bebas Asean ini. Perkembangan duniausahasemakin menuntut perusahaan berpacu untuk mengatasi persaingan yang semakin ketat dan kompleks, sehingga perusahaan dituntut harus mampu melaksanakan pengelolaan secara efektif dan efisien agar mampu mencapai tujuan yang diharapkan (Enny Istanti dan Bramastyo Kusumo, 2020:1). Pemerintah Indonesia harus lebih bekerja keras untuk meningkatkan kualitas SDM agar mampu bersaing di era Globalisasi dan pasar bebas saat ini. Globalisasi dan pasar bebas merupakan sesuatu yang tidak dapat dihindari. Dengan terbentuknya kawasan ekonomi terintegrasi di wilayah Asia Tenggara yang dikenal dengan istilah Masyarakat Ekonomi ASEAN (MEA) atau ASEAN Economic Community (AEC). Bagi sebuah perusahaan, untuk dapat bersaing dan tetap eksis dalam pangsa pasar yang begitu dinamis maka diperlukan manajemen pemasaran guna mendukung kegiatan perusahaan.Widiana (2019:1) mendefinisikan pemasaran adalah salah satu kegiatan pokok yang perlu dilakukan oleh perusahaan baik itu perusahaan barang atau jasa dalam upaya untuk mempertahankan kelangsungan hidup usahanya. Hal tersebut disebabkan karena pemasaran merupakan salah satu kegiatan perusahaan, dimana secara langsung berhubungan dengan konsumen. Priansa (2017:32), Manajemen Pemasaran adalah ilmu dan seni dalam melaksanakan fungsi-fungsi manajemen yang terdiri atas perencanaan, pengorganisasian, pengaktualisasian serta pengendalian dalam rangka menyampaikan produk dan nilai-nilai yang terkandung didalamnya dari produsen ke konsumen.

Indonesia dan sembilan anggota ASEAN lainnya memasuki persaingan yang sangat ketat di bidang ekonomi. MEA sebagai pasar tunggal di kawasan Asia Tenggara yang difungsikan sebagai sebuah kawasan kesatuan pasar dan basis produksi. Terciptanya kesatuan pasar dan basis produksi tersebut akan menghilangkan batasan terhadap arus barang, investasi, modal, jasa, dan tenaga profesional antar negara di Asia Tenggara. Dengan kehadiran MEA, maka masyarakat akan berusaha meningkatkan kualitas serta keterampilan pribadi agar dapat bersaing dengan masyarakat dari negara ASEAN lainnya.

Pada masa pandemi di sepanjang tahun 2020 ini, dimana di Indonesia maupaun dunia sedang ditimpa wabah Covid-19 yang meluluhlantakan berbagai macam sektor, khususnya sektor ekonomi. Penyebab anjloknya pertumbuhan ekonomi tersebut karena konsumsi rumah tangga, investasi dan konsumsi pemerintah yang turun. Konsumsi rumah tangga menurun menjadi 3,2 persen hingga 1,6 persen. Hal ini tidak lain adalah 
dampak dari mewabahnya Covid-19 di seluruh Indonesia (CNN Indonesia,2020). Untuk itu inovasi produk perlu dilakukan untuk menjaga minat beli dari konsumen. Salah satu dampak dari pandemic COVID-19 adalah pelaku bisnis yang kesulitan untuk memasarkan produk mereka, terlebih lagi merek yang telah dibangun sebelumnya menjadi tidak dikenal kembali dikarenakan pemerintah menetapkan pembatasan sosial berskala besar (PSBB) dan social distancing untuk menekan angka pertumbuhan kasus positif (Fadly \& Sutama, 2020.

Kotler \& Keller (2016:476), inovasi produk adalah "An innovation is any good, service, or idea that someone perceives as new, no matter how long its history, the spread of a new idea from its source of invention or creation to its ultimate users or adopters". Yang artinya inovasi adalah produk yang bagus, layanan, atau ide yang dianggap baru oleh seseorang, tidak peduli berapa lama sejarahnya, atau penyebaran ide baru dari sumber penemuan atau kreasi pengguna. Maulana \& Alisha (2020), inovasi produk merupakan gabungan dari macam-macam proses yang saling mempengaruhi, dimana perusahaan menciptakan sebuah produk baru yang diperkenalkan ke pasar. Inovasi produk seharusnya mampu memberikan nilai tambah dibandingkan dengan produk sejenis (keunggulan produk) sehingga dapat menjadikan perusahaan memiliki keunggulan dalam pesaingnya. Hubungan antara inovasi produk dan minat beli konsumen dijelaskan oleh Dhewanto et. al. (2015:105), bahwa inovasi produk yang dilakukan oleh perusahaan mampu memenuhi kebutuhan para penggunanya. Dalam hal ini ketika kebutuhan konsumen dirasa akan terpenuhi maka akan memunculkan minat beli konsumen akan produk tersebut.

Promosi menjadi salah satu faktor penting dalam pemasaran. Kotler \& Keller (2016:47) menyebutkan promosi merupakan suatu unsur yang digunakan untuk memberitahukan atau membujuk pasar tentang produk atau jasa yang baru pada perusahaan melalui iklan, penjualan pribadi, promosi penjualan, maupun publikasi. Tondang (2018) menyatakan bahwa promosi adalah arus informasi atau persuatif satu arah yang di buat untuk mengarahkan seseorang atau organisasi kepada tindakan yang menciptakan pertukaran dalam pemasaran semua jenis kegiatan yang mendorong permintaan. Hubungan antara promosi dan minat beli konsumen dijelaskan Malau (2017:103), Promosi adalah bentuk persuasi langsung melalui penggunaan berbagai insentif yang dapat diatur untuk merangsang pembelian produk dan meningkatkan jumlah yang dibeli pelanggan serta membuat konsumen puas sehingga melakukan pembelian. Dalam hal ini promosi yang dilakukan perusahaan dapat memunculkan minat beli yang nantinya akan menciptakan kepuasan konsumen.

Priansa (2017:351), Electronic Word Of Mouth adalah pernyataan yang dibuat oleh konsumen aktual, potensial, atau konsumen sebelumnya yang membicarakan mengenai produk atau perusahaan dan informasi ini tersedia bagi orang-orang ataupun institusi melalui media internet.

Amalia dan Zuliestian (2020) mendefinisikan electronic Word of Mouth sebagai setiap derajat atau kombinasi positif, negatif, atau komentar netral, rekomendasi, atau pernyataan tentang perusahaan, merek, produk, atau jasa yang dibahas atau dibagikan antara konsumen pada format digital atau elektronik. Hubungan antara promosi dan minat beli konsumen Priansa (2017:356) adalah electronic Word of Mouth (eWOM) membantu konsumen mengeluarkan opini dan pendapat mengenai produk perusahaan yang mana dapat memotivasi konsumen dalam untuk terlibat dan pada akhirnya mempengaruhi keputusan pembelian bagi dirinya sendiri maupun konsumen yang lain. 
Citra merek juga menjadi faktor yang dapat melancarkan kegiatan pemasaran. Priansa (2017:265) mengatakan bahwa citra merek merupakan keseluruhan kesan yang terbentuk dalam benak masyarakat tentang perusahaan. Citra merek berhubungan dengan nama bisnis, arsitektur, tradisi, ideologi, dan kesan pada kualitas komunikasi yang dilakukan oleh setiap karyawan yang berinteraksi dengan klien perusahaan. Satria dan Sidharta (2017) dalam menyebutkan citra merek atau brand image adalah seberapa konsumen melihat merek tertentu, sementara identitas merek adalah metode di mana perusahaan meluncurkan merek mereka di pasar dan persepsi konsumen seperti yang diinginkan oleh merek tersebut di pasar. Hubungan antara citra merek dan minat beli konsumen Priansa (2017:267) adalah citra merek yang baik akan berdampak positif bagi perusahaan karena mampu memberikan kepuasan kepada pelanggan dan juga meningkatkan daya tarik konsumen untuk menggunakan suatu barang atau jasa. Daya tarik yang dimaksud dalam hal ini adalah minat beli konsumen terhadap produk tersebut.

\section{TINJAUAN PUSTAKA}

\section{Inovasi Produk}

Menurut Dhewanto et al. (2015:105) menyatakan bahwa inovasi produk bukan hanya merupakan sebuah pengembangan produk, namun inovasi produk juga dapat berupa pengenalan produk baru, mengonsep ulang dalam rangka meningkatkan barang atau jasa yang dihasilkan oleh perusahaan. Inovasi tidak hanya diukur berdasarkan seberapa besar perubahan yang dibuat terhadap produk, namun ukuran sebuah inovasi juga berdasarkan seberapa besar terpenuhinya kebutuhan para penggunanya. Menurut Kotler dan Keller (2016:476), inovasi produk adalah "An innovation is any good, service, or idea that someone perceives as new, no matter how long its history, the spread of a new idea from its source of invention or creation to its ultimate users or adopters". Yang artinya inovasi adalah produk yang bagus, layanan, atau ide yang dianggap baru oleh seseorang, tidak peduli berapa lama sejarahnya, atau penyebaran ide baru dari sumber penemuan atau kreasi pengguna. Berdasarkan pendapat di atas, disimpulkan bahwa inovasi produk adalah suatu kemampuan penciptaan dalam menambahkan nilai guna/manfaat, pemilihan dan pengembangan atau peningkatan produk terhadap suatu produk dan menjaga mutu produk sehingga produk tersebut berbeda dengan bentuk awal.

\section{Indikator Inovasi Produk}

Dhewanto et. al. (2015:108-109) menjelaskan bahwa inovasi produk dapat diukur dengan kualitas produk, fitur produk serta desain produk.

a. Fitur produk.

b. Desain produk.

c. Kualitas produk.

\section{Promosi}

Kotler dan Keller (2016:78), promosi merupakan suatu unsur yang digunakan untuk memberitahukan atau membujuk pasar tentang produk atau jasa yang baru pada perusahaan melalui iklan, penjualan pribadi, promosi penjualan, maupun publikasi. Setyaningrum (2015:223), promosi adalah sebuah mekanisme komunikasi pemasaran, pertukaran informasi antara pembeli dan penjual. Malau (2017:103) mengatakan bahwa "Promosi adalah bentuk persuasi langsung melalui penggunaan berbagai insentif yang 
dapat diatur untuk merangsang pembelian produk dengan segera dan atau meningkatkan jumlah yang dibeli pelanggan serta membuat konsumen puas sehingga melakukan pembelian kembali". Dari beberapa pengertian diatas dapat disimpulkan bahwa promosi adalah suatu usaha komunikasi dari produsen untuk mengenalkan produknya kepada konsumen dengan tujuan untuk mencari laba.

\section{Indikator Promosi}

Indikator promosi dijelaskan Kotler dan Keller (2016:582) terdiri dari:

a. Advertising (Iklan).

b. Sales promotion (Promosi Penjualan).

c. Events and experiences (Acara dan pengalaman).

d. Public Relation and publicity (Hubungan masyarakat dan publisitas).

e. Direct Marketing and database (Pemasaran langsung).

f. Online and social media marketing (Pemasaran online dan media sosial).

g. Mobile marketing (Pemasaran mobile).

h. Personal Selling (Penjualan personal).

\section{Electronic Word Of Mouth (eWOM)}

Priansa (2017:351), Electronic Word Of Mouth adalah pernyataan yang dibuat oleh konsumen aktual, potensial, atau konsumen sebelumnya yang membicarakan mengenai produk atau perusahaan dan informasi ini tersedia bagi orang-orang ataupun institusi melalui media internet. Electronic Word of Mouth sebagai setiap derajat atau kombinasi positif, negatif, atau komentar netral, rekomendasi, atau pernyataan tentang perusahaan, merek, produk, atau jasa yang dibahas atau dibagikan antara konsumen pada format digital atau elektronik (Amalia \& Zuliestian, 2020).

\section{Indikator Electronic Word Of Mouth (eWOM)}

Priansa (2017:354), menyebutkan Electronic Word Of Mouth dapat diukur melalui indikator berikut ini:

a. Intensitas (Intensity).

b. Pendapat konsumen (Valence of opinion).

c. Isi Informasi (Content).

\section{Citra Merek}

Priansa (2017:265) menyebutkan bahwa citra merek merupakan respon dari konsumen pada keseluruhan penawaran yang diberikan oleh perusahaan. Citra perusahaan dapat dipahami juga sebagai sejumlah kepercayaan dan kesan pelanggan terhadap perusahaan. Citra merek merupakan keseluruhan kesan yang terbentuk dalam benak masyarakat tentang perusahaan. Citra merek berhubungan dengan nama bisnis, arsitektur, tradisi, ideologi, dan kesan pada kualitas komunikasi yang dilakukan oleh setiap karyawan yang berinteraksi dengan klien perusahaan. Kotler dan Amastrong (2018:233), mendefinisikan citra merek adalah "The set of belief held about a particular brand is known as brand image". Kotler dan Keller (2016:193) menyatakan bahwa citra merek adalah "all brand-related thoughts, feelings, perceptions, images, experiences, beliefs, attitudes, and so on, that become linked to the brand node". Berdasarkan definisi dari beberapa ahli tentang citra merek, dapat disimpulkan bahwa citra merek merupakan suatu kepercayaan mengenai merek berupa pikiran, perasaan, persepsi, citra, pengalaman, kepercayaan dan perilaku mengenai 
pandangan konsumen kepada merek baik berasosiasi secara positif atau negatif yang memungkinkan konsumen untuk melakukan pembelian.

\section{Indikator Citra Merek}

Adapun indikator citra merek dalam Amilia (2017) yaitu sebagai berikut:

a. Atribut produk (product attribute)

b. Keuntungan konsumen (consumer benefits)

c. Kepribadian merek (brand personality).

\section{Minat Beli}

Minat (Interest) berarti kecenderungan atau kegiatan yang tinggi atau keinginan yang besar terhadap sesuatu. Kamus Besar Bahasa Indonesia (KBBI) mengartikan minat sebagai sebuah kecenderungan hati yang tinggi terhadap suatu gairah atau keinginan. Minat beli merupakan sumber motivasi yang berdampak untuk mendorong seseorang melakukan pembelian apa yang diinginkannya (Kinarsih, 2015). Minat Beli adalah sesuatu yang berhubungan dengan rencana konsumen untuk membeli produk tertentu serta berapa banyak unit produk yang dibutuhkan pada periode tertentu. Dapat dikatakan bahwa minat beli adalah motivasi yang terkumpul dari konsumen untuk membeli produk setelah mengetahui kualitas produk itu. Sedangkan untuk mendorong terjadinya minat beli, perlu dibangun keyakinan dari diri konsumen bahwa produk tersebut akan memuaskan sehingga konsumen memiliki keinginan untuk memiliki produk tersebut dengan cara membelinya (Negara et al., 2018).

\section{Indikator Minat Beli}

Indikator minat beli dalam Negara et al., (2018) adalah sebagai berikut:

1. Minat Transaksional

2. Minat Referensial

3. Minat Preferensial

4. Minat Eksploratif

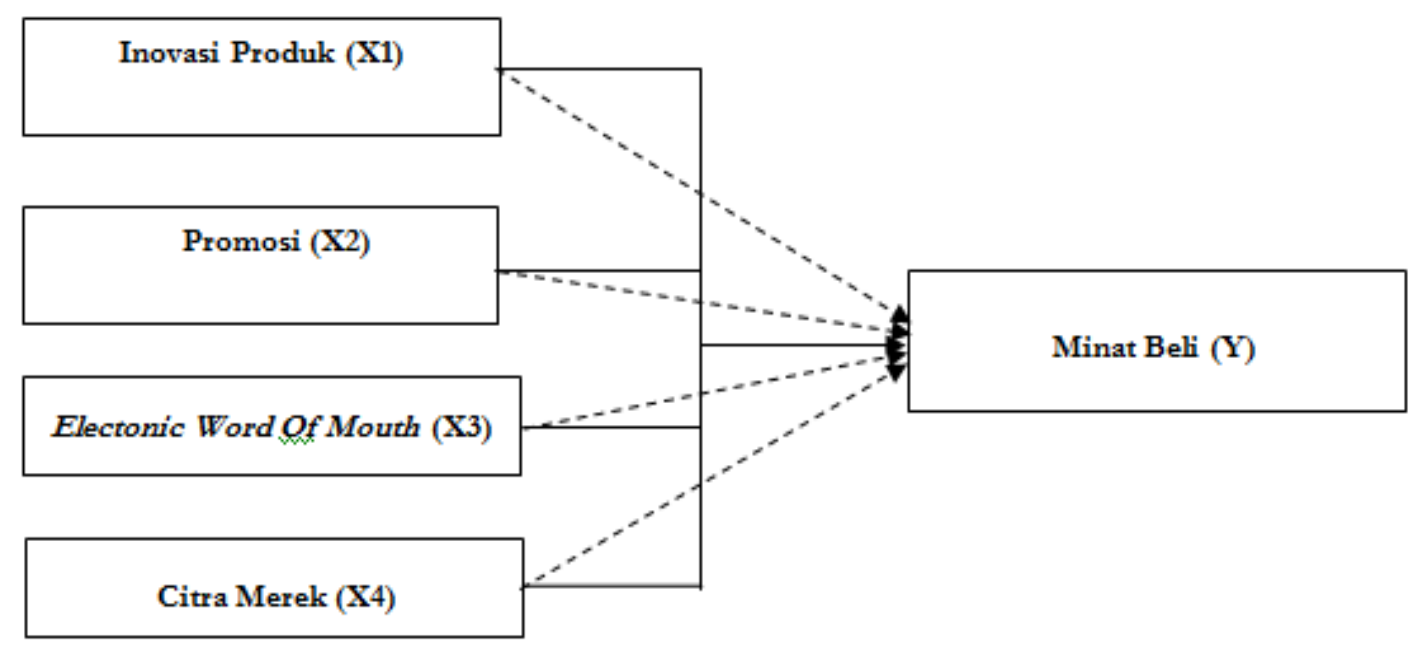

\section{Gambar 1}

Kerangka Konseptual 


\section{Hipotesis}

Sugiyono (2015:63) menyatakan bahwa hipotesis merupakan jawaban sementara terhadap rumusan masalah penelitian, dalam bentuk kerangka konseptual hipotesis dari penelitian ini yaitu sebagai berikut:

a. Bahwa variabel Inovasi Produk, Promosi, Electronic Word Of Mouth (eWOM) dan Citra Merek berpengaruh secara simultan dan signifikan terhadap Minat Beli Produk Pucelle Pada Masa Pandemi Covid-19 di Surabaya.

b. Bahwa variabel Inovasi Produk, Promosi, Electronic Word Of Mouth (eWOM) dan Citra Merek berpengaruh secara parsial dan signifikan terhadap Minat Beli Produk Pucelle Pada Masa Pandemi Covid-19 di Surabaya.

c. Bahwa variabel Electronic Word Of Mouth berpengaruh dominan terhadap Minat Beli Produk Pucelle Pada Masa Pandemi Covid-19 di Surabaya.

\section{METODE PENELITIAN}

\section{Lokasi Dan Waktu Penelitian}

Adapun lokasi yang diteliti oleh penulis adalah di Kota Surabaya. Waktu penelitian berlangsung mulai bulan Juli 2020 sampai Juli 2021. Obyek yang diteliti adalah konsumen Pucelle di Surabaya.

\section{Pendekatan Penelitian}

Pendekatan dilakukan dengan pendekatan kuantitatif yang merupakan data diperoleh dari hasil perhitungan dan pengukuran. Jenis data yang digunakan penulis dalam penelitian ini adalah data primer. Sugiyono (2015:225), data primer adalah data yang langsung diperoleh dan diberikan langsung kepada pengumpul data.

\section{Metode Pengumpulan Data}

Metode pengumpulan data merupakan suatu cara untuk memperoleh data-data yang diperlukan dalam penelitian. data yang didapatkan menggunakan metode kuesioner. Kuesioner merupakan teknik pengumpulan data yang dilakukan dengan memberi seperangkat pertanyaan atau pernyataan tertulis kepada responden untuk dijawab (Sugiyono (2015:142).

\section{Analisis Data}

Analisis data dalam penelitian ini adalah metode analisis data kualitatif dengan menggunkan alat uji data program Statistical Panckage for Social Sciences (SPSS). Kemudian untuk uji yang digunakan yaitu uji regresi linier berganda, uji koefien determinsi, uji F, uji t dan pembuktian dominan.

\section{HASIL ANALISIS DAN PEMBAHASAN}

\section{Uji Validitas}

Berdasarkan hasil Tabel 1 menunjukkan bahwa semua indikator memiliki $\mathrm{r}$ hitung $>\mathrm{r}$ tabel yaitu sebesar 0,2006. Maka dapat disimpulkan bahwa semua pernyataan untuk variabel adalah valid dan dapat dilanjutkan ke pengujian selanjutnya.

\section{Uji Reliabilitas}

Berdasarkan Tabel 2 dapat diketahui bahwa hasil Cronbach's Alpha setiap variabel lebih dari standar Cronbach's Alpha yang diisyaratkan yaitu 0,60. Maka variabel Inovasi Produk, 
Promosi, Electronic Word of Mouth (eWOM) dan Citra Merek dan Minat Beli reliabel, semua pernyataan memiliki tingkat keandalan yang baik dan dapat digunakan dalam analisis penelitian selanjutnya.

\section{Uji Analisis Regresi Linier Berganda}

Berdasarkan hasil uji pada tabel 3 dapat diketahui bahwa naik turunnya suatu variable artinya jika variabel bebas inovasi produk, promosi, electronic word of mouth dan citra merek mengalami kenaikan satu satuan maka variabel terikat minat beli akan mengalami kenaikan.

\section{Uji Koefisien Determinasi (Adjust $R$ Square)}

Pada Tabel 4 diperoleh nilai $\mathrm{R}$ Square $=0,598=59,8 \%$. Ini berarti variabel bebas Inovasi Produk, Promosi, Electronic Word of Mouth (eWOM) dan Citra Merek secara bersama-sama mempengaruhi variabel bebas Minat Beli sebesar 59,8\% dan sisanya $40,2 \%$ dipengaruhi oleh variabel lain yang tidak masuk dalam penelitian ini.

Tabel 1

\section{Uji Validitas}

\begin{tabular}{|c|c|c|c|c|c|}
\hline Variabel & Indikator & r hitung & Tanda & r Tabel & Keterangan \\
\hline \multirow{3}{*}{ Inovasi Produk (X1) } & $\mathrm{X} 1.1$ & 0,780 & $>$ & 0,2006 & Valid \\
\hline & $\mathrm{X} 1.2$ & 0,800 & $>$ & 0,2006 & Valid \\
\hline & $\mathrm{X} 1.3$ & 0,797 & $>$ & 0,2006 & Valid \\
\hline \multirow{8}{*}{ Promosi (X2) } & $\mathrm{X} 2.1$ & 0,614 & $>$ & 0,2006 & Valid \\
\hline & $\mathrm{X} 2.2$ & 0,634 & $>$ & 0,2006 & Valid \\
\hline & $\mathrm{X} 2.3$ & 0,544 & $>$ & 0,2006 & Valid \\
\hline & $\mathrm{X} 2.4$ & 0,531 & $>$ & 0,2006 & Valid \\
\hline & $\mathrm{X} 2.5$ & 0,403 & $>$ & 0,2006 & Valid \\
\hline & $\mathrm{X} 2.6$ & 0,479 & $>$ & 0,2006 & Valid \\
\hline & $\mathrm{X} 2.7$ & 0,534 & $>$ & 0,2006 & Valid \\
\hline & $\mathrm{X} 2.8$ & 0,508 & $>$ & 0,2006 & Valid \\
\hline \multirow{3}{*}{$\begin{array}{l}\text { Electronic Word Of Mouth } \\
\text { (eWOM) (X3) }\end{array}$} & X3.1 & 0,743 & $>$ & 0,2006 & Valid \\
\hline & $\mathrm{X} 3.2$ & 0,844 & $>$ & 0,2006 & Valid \\
\hline & X3.3 & 0,668 & $>$ & 0,2006 & Valid \\
\hline \multirow{3}{*}{ Citra Merek (X4) } & $\mathrm{X} 4.1$ & 0,787 & $>$ & 0,2006 & Valid \\
\hline & $\mathrm{X} 4.2$ & 0,785 & $>$ & 0,2006 & Valid \\
\hline & $\mathrm{X} 4.3$ & 0,767 & $>$ & 0,2006 & Valid \\
\hline \multirow{4}{*}{ Minat Beli (Y) } & Y1.1 & 0,614 & $>$ & 0,2006 & Valid \\
\hline & Y1.2 & 0,711 & $>$ & 0,2006 & Valid \\
\hline & Y1.3 & 0,736 & $>$ & 0,2006 & Valid \\
\hline & Y1.4 & 0,663 & $>$ & 0,2006 & Valid \\
\hline
\end{tabular}

Sumber: Data Diolah (2021) 
Tabel 2

Uji Reliabilitas

\begin{tabular}{|c|c|c|c|c|c|}
\hline No & Variabel & $\begin{array}{l}\text { Cronbach's } \\
\text { Alpha }\end{array}$ & Tanda & $\begin{array}{c}\text { Minimal } \\
\text { Cronbach's Alpha } \\
\text { yang diisyaratkan }\end{array}$ & Keterangan \\
\hline 1 & Inovasi Produk & 0,702 & $>$ & 0,60 & Reliabel \\
\hline 2 & Promosi & 0,609 & $>$ & 0,60 & Reliabel \\
\hline 3 & $\begin{array}{l}\text { Electronic Word Of Mouth } \\
\text { (eWOM) }\end{array}$ & 0,616 & $>$ & 0,60 & Reliabel \\
\hline 4 & Citra Merek & 0,639 & $>$ & 0,60 & Reliabel \\
\hline 5 & Minat Beli & 0,610 & $>$ & 0,60 & Reliabel \\
\hline
\end{tabular}

Sumber: Data Diolah (2021)

Tabel 3

Uji Analisis Regresi Linier Berganda Coefficients $^{\mathrm{a}}$

\begin{tabular}{|c|c|c|c|c|c|c|}
\hline \multirow{2}{*}{\multicolumn{2}{|c|}{ Model }} & \multicolumn{2}{|c|}{$\begin{array}{l}\text { Unstandardized } \\
\text { Coefficients }\end{array}$} & \multirow{2}{*}{$\begin{array}{c}\text { Standardized } \\
\text { Coefficients } \\
\text { Beta }\end{array}$} & \multirow[b]{2}{*}{$\mathrm{t}$} & \multirow[b]{2}{*}{ Sig. } \\
\hline & & $\mathrm{B}$ & Std. Error & & & \\
\hline \multirow[t]{5}{*}{1} & (Constant) & .068 & .379 & & .178 & .859 \\
\hline & Inovasi Produk (X1) & .195 & .077 & .226 & 2.551 & .012 \\
\hline & Promosi (X2) & .220 & .109 & .159 & 2.018 & .047 \\
\hline & $\begin{array}{l}\text { Electronic Word Of } \\
\text { Mouth (X3) }\end{array}$ & .356 & .075 & .394 & 4.775 & .000 \\
\hline & Citra Merek (X4) & .233 & .091 & .211 & 2.556 & .012 \\
\hline
\end{tabular}

Sumber: Data Diolah (2021)

Tabel 4

\section{Uji Koefisien Determinisasi} Model Summary

\begin{tabular}{lccccc}
\hline Model & R & R Square & \multicolumn{2}{c}{ Adjusted R Square } & \multicolumn{2}{c}{ Std. Error of the Estimate } \\
\hline 1 & $.773^{a}$ & .598 & .580 & .30415 \\
\hline
\end{tabular}

a. Predictors: (Constant), Citra Merek (X4), Electronic Word Of Mouth (X3), Promosi (X2), Inovasi Produk (X1)

Sumber: Data Diolah (2021)

Tabel 5

Uji Simultan (uji F)

ANOVA $^{\mathrm{b}}$

\begin{tabular}{llrrrrr}
\hline Model & Sum of Squares & Df & \multicolumn{2}{c}{ Mean Square } & F & \multicolumn{2}{c}{ Sig. } \\
\hline 1 & Regression & 12.517 & 4 & 3.129 & 33.828 & $.000^{a}$ \\
& Residual & 8.418 & 91 & .093 & & \\
\hline Total & 20.935 & 95 & & & \\
\hline
\end{tabular}

a. Predictors: (Constant), Citra Merek (X4), Electronic Word Of Mouth (X3), Promosi (X2), Inovasi Produk (X1)

b. Dependent Variable: Minat Beli $(\mathrm{Y})$

Sumber: Data Diolah (2021) 


\begin{tabular}{|c|c|c|c|c|c|c|c|}
\hline \multicolumn{8}{|c|}{$\begin{array}{c}\text { Tabel } 6 \\
\text { Uji Parsial (Uji t) } \\
\text { Coefficients }^{\mathrm{a}}\end{array}$} \\
\hline \multirow{2}{*}{\multicolumn{2}{|c|}{$\underline{\text { Model }}$}} & \multicolumn{2}{|c|}{$\begin{array}{l}\text { Unstandardized } \\
\text { Coefficients } \\
\end{array}$} & \multicolumn{2}{|c|}{$\begin{array}{c}\text { Standardized } \\
\text { Coefficients }\end{array}$} & \multirow{2}{*}{\multicolumn{2}{|c|}{ Sig. }} \\
\hline & & $\mathrm{B}$ & Std. Error & Beta & t & & \\
\hline \multirow[t]{5}{*}{1} & (Constant) & .068 & .3 & & & .178 & .859 \\
\hline & Inovasi Produk (X1) & .195 & .0 & & .226 & 2.551 & .012 \\
\hline & Promosi (X2) & .220 & & & .159 & 2.018 & .047 \\
\hline & $\begin{array}{l}\text { Electronic Word Of Mouth } \\
\text { (X3) }\end{array}$ & .356 & .0 & & .394 & 4.775 & .000 \\
\hline & Citra Merek (X4) & .233 & & & .211 & 2.556 & .012 \\
\hline
\end{tabular}

a. Dependent Variable: Minat Beli $(\mathrm{Y})$

Sumber: Data Diolah (2021)

\section{Uji F Simultan}

Uji simultan pada tabel 5 ditunjukkan dengan hasil perhitungan $\mathrm{F}$ hitung yang menunjukan nilai 33,828. Sedangkan dengan rumus hitung $F$ tabel $(k ; n-k-1)$ yaitu (4;91) dengan propabilitas 5\% diperoleh $\mathrm{F}$ tabel sebesar 2,47. Untuk uji simultan menggunakan nilai signifikansi (Sig.) dari output Anova diperoleh nilai Sig. sebesar 0,000 yang berarti dibawah 0,05 (alpha 5\%). Hal ini berarti variabel bebas (independent) antara variabel Inovasi Produk, Promosi, Electronic Word Of Mouth (eWOM) dan Citra Merek secara bersama-sama berpengaruh terhadap Minat Beli. Dengan demikian dapat disimpulkan bahwa Hipotesis diterima.

\section{Uji t (Parsial)}

Tabel 6 menunjukkan bahwa dari variabel Inovasi Produk dapat disimpulkan mengenai uji $\mathrm{t}$ (parsial) ditunjukkan dengan hasil perhitungan $\mathrm{t}$ hitung yang menunjukkan nilai 2,551 . Sedangkan dengan rumus $\mathrm{t}$ tabel $(\alpha / 2 ; \mathrm{n}-\mathrm{k})$ yaitu $(0,025: 92)$ diperoleh $\mathrm{t}$ tabel sebesar 1.98609 yang berarti t hitung $>\mathrm{t}$ tabel. Untuk uji parsial menggunakan nilai signifikansi (Sig.) diperoleh nilai Sig. sebesar 0,012 yang berarti dibawah 0,05 (alpha 5\%). Hal ini berarti Inovasi Produk secara parsial berpengaruh positif terhadap Minat Beli.

Tabel 6 terdapat variabel Promosi dapat disimpulkan mengenai uji t (parsial) ditunjukkan dengan hasil perhitungan t hitung yang menunjukkan nilai 2,018. Sedangkan dengan rumus t tabel $(\alpha / 2 ; \mathrm{n}-\mathrm{k})$ yaitu $(0,025: 92)$ diperoleh $\mathrm{t}$ tabel sebesar 1.98609 yang berarti $\mathrm{t}$ hitung $>\mathrm{t}$ tabel. Untuk uji parsial menggunakan nilai signifikansi (Sig.) diperoleh nilai Sig. sebesar 0,047 yang berarti dibawah 0,05 (alpha 5\%). Hal ini berarti Promosi secara parsial berpengaruh positif terhadap Minat Beli.

Dari Tabel 6 dari variabel Electronic Word of Mouth (eWOM) dapat disimpulkan mengenai uji $\mathrm{t}$ (parsial) ditunjukkan dengan hasil perhitungan $\mathrm{t}$ hitung yang menunjukkan nilai 4,775. Sedangkan dengan rumus t tabel $(\alpha / 2 ; n-k)$ yaitu $(0,025: 92)$ diperoleh $\mathrm{t}$ tabel sebesar 1.98609 yang berarti $\mathrm{t}$ hitung $>\mathrm{t}$ tabel. Untuk uji parsial menggunakan nilai signifikansi (Sig.) diperoleh nilai Sig. sebesar 0,000 yang berarti dibawah 0,05 (alpha 5\%). Hal ini berarti Electronic Word of Mouth (eWOM) secara parsial berpengaruh positif terhadap Minat Beli. 
Dari Tabel 6 dari variabel Citra Merek dapat disimpulkan mengenai uji t (parsial) ditunjukkan dengan hasil perhitungan t hitung yang menunjukkan nilai 2,556. Sedangkan dengan rumus $\mathrm{t}$ tabel $(\alpha / 2 ; \mathrm{n}-\mathrm{k})$ yaitu $(0,025: 92)$ diperoleh $\mathrm{t}$ tabel sebesar 1.98609 yang berarti $\mathrm{t}$ hitung $>\mathrm{t}$ tabel. Untuk uji parsial menggunakan nilai signifikansi (Sig.) diperoleh nilai Sig. sebesar 0,012 yang berarti dibawah 0,05 (alpha 5\%). Hal ini berarti Citra Merek secara parsial berpengaruh positif terhadap Minat Beli.

\section{Pembuktian Variabel Dominan}

Dari keempat variabel bebas yang terdiri dari Inovasi Produk, Promosi, Electronic Word of Mouth (eWOM) dan Citra Merek dapat diketahui bahwa variabel Electronic Word of Mouth (eWOM) mempunyai nilai koefisien $(\beta)$ terbesar yaitu 0,394 yang merupakan nilai terbesar diantara variabel-variabel bebas lainnya. Sehingga dapat disimpulkan bahwa variabel bebas yang berpengaruh dominan terhadap variabel terikat Minat Beli adalah variabel Electronic Word of Mouth (eWOM).

\section{Pembahasan}

\section{Uji Hipotesis Pertama Secara Simultan (Uji F)}

Hasil penelitian menunjukkan bahwa uji simultan diperoleh $\mathrm{F}$ hitung sebesar 33,828 dengan signifikan sebesar 0,000 . Oleh karena $F$ hitung $(33,828)>F$ tabel $(2,47)$ dan nilai signifikan yang dihasilkan sebesar $0,000<$ á $=(0,05)$, maka dapat disimpulkan bahwa $\mathrm{H}_{\mathrm{o}}$ ditolak dan $\mathrm{H}_{1}$ diterima. Artinya bahwa variabel Inovasi Produk, Promosi, Electronic Word of Mouth (eWOM) dan Citra Merek secara simultan (bersama-sama) berpengaruh signifikan terhadap variabel Minat Beli.

\section{Uji Hipotesis Kedua Secara Parsial (Uji t)}

\section{Pengaruh Inovasi Produk Terhadap Minat Beli}

Dalam penelitian ini, pengujian secara parsial dengan uji t untuk mengetahui pengaruh variabel inovasi produk terhadap minat beli diperoleh $t$ hitung untuk variabel inovasi produk 2,551 dengan tingkat signifikansi 0,012. Oleh karena t hitung $(2,551)>t$ tabel (1.98609) dan nilai signifikan yang dihasilkan 0,012 lebih kecil dari á $=(0,05)$, maka $\mathrm{H}_{\text {o }}$ ditolak dan $\mathrm{H}_{1}$ diterima. Artinya variabel inovasi produk secara parsial berpengaruh signifikan terhadap variabel terikat minat beli.

Tabel 7

\section{Uji Dominan}

Coefficients $^{a}$

\begin{tabular}{|c|c|c|c|c|c|}
\hline \multirow[b]{2}{*}{ Model } & \multicolumn{2}{|c|}{$\begin{array}{l}\text { Unstandardized } \\
\text { Coefficients }\end{array}$} & \multicolumn{2}{|c|}{$\begin{array}{l}\text { Standardized } \\
\text { Coefficients }\end{array}$} & \multirow[b]{2}{*}{ Sig. } \\
\hline & $\overline{\mathrm{B}}$ & Std. Error & Beta & $\mathrm{t}$ & \\
\hline (Constant) & .068 & .379 & & .178 & .859 \\
\hline Inovasi Produk (X1) & .195 & .077 & .226 & 2.551 & .012 \\
\hline Promosi (X2) & .220 & .109 & .159 & 2.018 & .047 \\
\hline $\begin{array}{l}\text { Electronic Word of Mouth } \\
\text { (X3) }\end{array}$ & .356 & .075 & .394 & 4.775 & .000 \\
\hline Citra Merek (X4) & .233 & .091 & .211 & 2.556 & .012 \\
\hline
\end{tabular}

a. Dependent Variable: Minat Beli (Y)

Sumber: Data Diolah (2021) 


\section{Pengaruh Promosi Terhadap Minat Beli}

Dalam penelitian ini, pengujian secara parsial dengan uji t untuk mengetahui pengaruh variabel promosi terhadap minat beli diperoleh t hitung untuk variabel promosi 2,018 dengan tingkat signifikansi 0,047 . Oleh karena t hitung $(2,018)>t$ tabel $(1.98609)$ dan nilai signifikan yang dihasilkan 0,047 lebih kecil dari á $=(0,05)$, maka $\mathrm{H}_{\mathrm{o}}$ ditolak dan $\mathrm{H}_{1}$ diterima. Artinya variabel promosi secara parsial berpengaruh signifikan terhadap variabel terikat minat beli.

\section{Pengaruh Electronic Word of Mouth (eWOM) Terhadap Minat Beli}

Dalam penelitian ini, pengujian secara parsial dengan uji t untuk mengetahui pengaruh variabel Electronic Word of Mouth (eWOM) terhadap minat beli diperoleh t hitung untuk variabel Electronic Word of Mouth (eWOM) 4,775 dengan tingkat signifikansi 0,000. Oleh karena t hitung $(4,775)>t$ tabel (1.98609) dan nilai signifikan yang dihasilkan 0,000 lebih kecil dari á $=(0,05)$, maka Hipotesis diterima. Artinya variabel Electronic Word of Mouth (eWOM) secara parsial berpengaruh signifikan terhadap variabel terikat minat beli.

\section{Pengaruh Citra Merek Terhadap Minat Beli}

Dalam penelitian ini, pengujian secara parsial dengan uji t untuk mengetahui pengaruh variabel citra merek terhadap minat beli diperoleh t hitung untuk variabel citra merek 2,556 dengan tingkat signifikansi 0,012. Oleh karena t hitung (2,556)>t tabel (1.98609) dan nilai signifikan yang dihasilkan 0,012 lebih kecil dari á $=(0,05)$, maka Hipotesis diterima. Artinya variabel citra merek secara parsial berpengaruh signifikan terhadap variabel terikat minat beli.

\section{Pengaruh Dominan}

Dari keempat variabel yang terdiri dari Inovasi Produk, Promosi, Electronic Word of Mouth (eWOM) dan Citra Merekdapat diketahui bahwa variabel Electronic Word of Mouth (eWOM) nilai koefisien $\beta$ (beta) terbesar yang merupakan nilai terbesar diantara variabelvariabel bebas yang lain. Sehingga dapat disimpulkan bahwa variabel yang berpengaruh dominan terhadap variabel terikat minat beli adalah variabel Electronic Word of Mouth (eWOM). Hal ini dikarenakan Electronic Word of Mouth (eWOM) yang dilakukan oleh konsumen dapat mempengaruhi konsumen lain atau masyarakat untuk yang bertujuan meningkatkan keputusan membeli serta memakai produk Pucelle agar penjualan dapat meningkat.

\section{SIMPULAN DAN SARAN}

Sehingga dapat disimpulkan dari penelitian Uji F variabel Inovasi Produk (X1), Promosi (X2), eWOM (X3) dan Citra Merek (X4) terbukti secara simultan berpengaruh signifikan terhadap Minat Beli (Y). Dari penelitian Uji t variabel Inovasi Produk (X1), Promosi (X2), eWOM (X3), dan Citra Merek (X4) terbukti secara parsial berpengaruh signifikan terhadap Minat Beli (Y). Berdasarkan Uji Dominan variabel Inovasi Produk (X1), Promosi (X2), eWOM (X3), dan Citra Merek (X4) dapat diketahui bahwa eWOM (X3) secara dominan berpengaruh signifikan terhadap minat beli $(Y)$. 


\section{DAFTAR PUSTAKA}

Achmad Daengs, G. S., Istanti, E., Bramastyo Kusuma Negoro, R. M., \& Sanusi, R. 2020. The aftermath of management actions on competitive advantage through process attributes at food and beverage industries export import in Perak Harbor of Surabaya. International Journal of Criminology and Sociology, 9, 1418-1425. https://doi.org/10.6000/19294409.2020.09.162.

Achmad Daengs, G. S., Istanti, E., Bramastyo Kusuma Negoro, R. M., \& Sanusi, R. 2020. The aftermath of management actions on competitive advantage through process attributes at food and beverage industries export import in Perak Harbor of Surabaya. International Journal of Criminology and Sociology, 9, 1418-1425. https://doi.org/10.6000/1929-4409.2020.09.162.

Achmad Daengs GS1, Enny Istanti2, M. Y. R. P. 2021. Challenges of Exchange Rate Fluctuation and Cpo Prices in Indonesia Palm Oil Industry. IJEBD, 04(03), 356362. https://doi.org/https://doi.org/10.29138/ijebd.v4i3.1379.

AMILIA, S. 2017. Pengaruh Citra Merek, Harga, dan Kualitas Produk terhadap Keputusan Pembelian Handphone Merek Xiaomi di Kota Langsa. Jurnal Manajemen Dan Keuangan Unsam, 6(1), 660-669.

CNN Indonesia. 2020. Sri Mulyani: Dampak Virus Corona Berat ke Perekonomian.

Destiana Wulan Amalia, \& Zuliestiana, D. A. 2020. Pengaruh Electronic Word of Mouth Di Media Sosial Youtube Terhadap Minat Beli Produk Kosmetik New Wardah Exclusive Series (Studi Kasus Kota-Kota Di Jawa Barat). Jurnal Mitra Manajemen, 4(6), 871-884. https://doi.org/10.52160/ejmm.v4i6.390.

Dhewanto, W., Indradewa, R., Ulfah, W. N., \& Rahmawati, S. 2015. Manajemen Inovasi untuk Usaha Kecil dan Mikero. CV. Alfabeta.

Enny Istanti, Bramastyo Kusumo, I. N. 2020. Implementasi Harga, Kualitas Pelayanan dan Pembelian Berulang pada Penjualan Produk Gamis Afifathin. Ekonomika'45, $8(1), 1-7$.

https://univ45sby.ac.id/ejournal/index.php/akuntansi45/article/view/64/50.

Enny Istanti, Amaliyah, Achmad Daengs, G. 2020. Work Productivity Through Compensation, Experiences, and Walfare Benefits PT Summit Otto Finance Surabaya. SINERGI, 10 (2), 27-36.

Fadly, H. D., \& Sutama. 2020. Membangun Pemasaran Online dan Digital Branding Ditengah Pandemi Covid-19. Jurnal Ecoment Global: Kajian Bisnis Dan Management, 5, 213-222. 
Istanti, E. 2019. Pengaruh Harga, Promosi dan Produk terhadap Keputusan Pembelian Di Restoran Burger King Kawasan Surabaya Plaza Surabaya. Ekonomika'45, 7(1), 16-22. https://doi.org/.1037//0033-2909.I26.1.78.

Istanti, E., Negoro, B. K., \& GS, A. D. 2021. Analysis of Factors Affecting Income Distribution Inequality in Indonesia 2009-2013 Period. (International Journal of Entrepreneurship and Business Development, 4(02), 157-163.

Istanti, E., Kn, R. M. B., \& Gs, A. D. 2021. Efforts to Empower MSMEs in Panci Village in Increasing Family Income (Study on MSMEs in Panci Village in Porong District, Sidoarja Regency ). 2021(2), 497-504.

Keller, K. 2016. Manajemen Pemasaran (pp. 120-323). https://doi.org/10.1016/j.electacta.2014.10.067.

Kinasih, S. 2015. Pengaruh Produk, Promosi Dan Store Atmosphere Terhadap Minat Beli Konsumen. Jurnal Ilmu Dan Riset Manajemen, 4(12).

Kotler, Philip, \& Amstrong, G. 2018. Principles of Marketing. Global Edition. Pearson.

Kotler, Phillip, \& Keller, K. L. 2016. Marketing Management. Edisi ke 15. Global Edition. Pearson.

Malau, H. 2017. Manajemen Pemasaran. CV. Alfabeta.

Maulana, Y. S., \& Alisha, A. 2020. Inovasi Produk dan Pengaruhnya terhadap Minat Beli Konsumen (Studi Kasus pada Restoran Ichi Bento Cabang Kota Banjar). Inovbiæ: Jurnal Inovasi Bisnis, 8 (1), 86. https://doi.org/10.35314/inovbiz.v8i1.1313. 